\title{
PRZESTRZEŃ PRACY PRACOWNIKÓW WARSZAWSKICH KORPORACJI - PERSPEKTYWA I KREACJA PRZESTRZENI PRZEZ DOSTAWCÓW WYPOSAŻENIA I USŁUG DLA BIUR
}

ABSTRACT Workspace in Warsaw's corporations - perception and creation of space delivered by suppliers of equipment and services for offices

In my dissertation research I work on Workspace in Warsaw's corporations. In this article I present a part of the creation of the space formed by the suppliers of equipment and services for offices. Despite my experience of cooperation with people creating office spaces, I have never focused on this phenomenon in terms of sociological issues. Ones again being a member of the Fair "Office Days", I decided to look more closely at the proposed solutions and trends, which follow suppliers. More than once, I was surprised by the exhibitors, who proposed an unreal vision of the ideal world, free from flaws not only regarding objects but also people. I realized that the "ideal office needs perfect employee" where employee should not embarrass colleagues who belong to this space. This vision reminded me of hyperspace proposed by J. Baudrillard, where hyperreal has become more important than the true or actual reality as a result of the replacement of signs of reality.

Słowa kluczowe: przestrzeń pracy, hiperprzestrzeń, przestrzeń warszawskich korporacji

Keywords: workspace, hyperspace, Warsaw corporate workspace 


\section{PRZESTRZEŃ PRACY}

Przestrzeń jest pojęciem szeroko definiowanym w naukach społecznych, jednak z formalnego punktu widzenia jest to przede wszystkim miejsce, gdzie człowiek przebywa. Jak podkreśla Bohdan Jałowiecki, temat przestrzeni społecznej należy do najbardziej naturalnych i podstawowych zainteresowań socjologii ${ }^{1}$. W ujęciu socjologii przestrzeń to swoista jakość spoteczno-kulturowa, która jest przedmiotem poznania, wartościowania, doświadczania, ksztattowania i użytkowania przez jednostki i grupy ludzkie². Przestrzeń pracy, która jest przedmiotem moich zainteresowań, jest więc unikalną, nie tylko materialną formą dużej części naszego życia. Spędzamy w niej od kilku do kilkunastu godzin dziennie, wykonujemy obowiązki służbowe, realizujemy w niej niższe i wyższe potrzeby, cele, komunikujemy się i wreszcie jesteśmy w nieustających relacjach. Dla osób kreujących tę strukturę zarówno fizyczna materia, jak i aspekt społeczny tej przestrzeni są niezwykle istotne ${ }^{3}$, ponieważ to właśnie człowiek stanowi sam o sobie; stanowi to, czym jest, posiadając przy tym zdolność tworzenia przestrzeni, w której się porusza. Florian Znaniecki rozróżnił przestrzeń w kontekście fizyczności i aspektów społecznych, gdzie społeczna kategoria przestrzeni jest elementem systemu wartości ${ }^{4}$. Rzeczy od wartości różnią, jego zdaniem, znaczenia. „Wartości przestrzenne” są różnorodnie doświadczane, ponieważ zależnie od kontekstu, w którym występują, są nacechowane innymi ocena$\mathrm{mi}^{5}$. Konsekwencją rożnych układów wartości jest odmienne postrzeganie i zachowanie się uczestników danej przestrzeni, często będące jedynie percepcją wąskiej grupy danych odbiorców. Przestrzeń pracy jest zatem zarówno materią, jak i percepcją (jednostki i grupy). Jednostki samostanowią o swojej przestrzeni, ale także przestrzeń oddziałuje na człowieka ${ }^{6}$, stymulując jego zachowania w określony sposób.

Przedmiotem moich zainteresowań jest przestrzeń pracy warszawskich korporacji. Jest to unikalna struktura, która została celowo zaprojektowana, aby uzyskać pożądaną percepcję obecnych i potencjalnych pracowników. Poprzez aranżację przedmiotami tworzy „wartości przestrzenne” nacechowane znamionami sukcesu, który przez większość społeczeństwa jest uznawany za czynnik jednoznacznie pozytywny. Z mojej analizy wynika, że przestrzeń pracy ma charakter zarówno podażowy, jak i popytowy. Podaż stanowią dostawcy wyposażenia i usług dla biur oraz architekci. Office managerowie, dyrektorzy administracyjny, osoby aranżujące biuro z perspektywy firmy mogą reprezentować grupę po stronie podaży, jak i popytu, zaś sami pracownicy, odbiorcy i uczest-

\footnotetext{
B. Jałowiecki, Spoteczne wytwarzanie przestrzeni, Warszawa 1988, s. 11.

2 J. Ziółkowski, Postowie, [w:] A. Wallis, Socjologia przestrzeni, wybór i oprac. E. Grabska-Wallis, M. Ofierska, Warszawa 1990.

3 H. Buczyńska-Garewicz, Miejsca, strony, okolice. Przyczynek do fenomenologii przestrzeni, Kraków 2006, Horyzonty Nowoczesności, 49.

4 F. Znaniecki, Zagadnienie wartości $w$ filozofii, Warszawa 1910, Wydawnictwo „Przegladu Filozoficznego".

5 Tenże, Socjologiczne podstawy ekologii ludzkiej, „Ruch Prawniczy, Ekonomiczny i Socjologiczny” 1938, z. 1.

6 E. Hall, Poza kultura, przeł. E. Goździak, Warszawa 1984.
} 
nicy tej przestrzeni tworzą na nią popyt. W poniższym artykule chciałabym skupić się jedynie na wąskiej grupie reprezentującej podaż, tzn. dostawcach wyposażenia i usług dla biur. Interesuje mnie ich wizja i kreacja przestrzeni biurowej, produkty, jakie oferują, sposób, w jakie je sprzedają, oraz podstawy koncepcji biura, które są dla nich wyznacznikiem „standardu” przestrzeni korporacji.

\section{BADANIE. OBSERWACJA UCZESTNICZĄCA}

Przed rozpoczęciem badań zadałam sobie pytanie, w jaki sposób przestrzeń korporacji jest kreowana oraz czemu służy ta kreacja. Swoje poszukiwania rozpoczęłam od analizy warszawskich targów Office Days 2013. Pracując w jednej z warszawskich korporacji, która zajmuje się doradztwem w zakresie poszukiwania optymalnych powierzchni biurowych, stałam się uczestnikiem targów w formie czynnej. Jako badaczka przyjęłam rolę socjolożki poszukującej opisu optymalnych, a zarazem nowoczesnych rozwiązań dla biur. Odwiedziłam każde z sześćdziesięciu trzech stanowisk wystawienniczych, wykonałam dokumentację fotograficzną, a także przeprowadziłam krótką rozmowę z osobami reprezentującymi daną firmę na temat oferowanych produktów i usług. Wśród moich rozmówców pojawili się nie tylko przedstawiciele handlowi, ale także office managerowie czy architekci, czyli osoby mające nieustanny kontakt z pracownikami i aranżacjami przestrzeni biurowych. Osoby reprezentujące daną firmę otrzymały ode mnie informację, iż poszukuję najnowszych rozwiązań dla przestrzeni biurowej kilku warszawskich korporacji. Poprosiłam je o opowiedzenie o swoim produkcie, usłudze, a także o informację, jak ich zdaniem dane rozwiązanie funkcjonuje w przestrzeni biurowej, jak jest odbierane przez pracowników. Nie poszukiwałam żadnych konkretnych rozwiązań, interesowały mnie produkty, usługi oraz sposób ich prezentacji. Celem mojego badania było stworzenie obrazu, kreacji, która jest oferowana bezpośrednio użytkownikom, firmom i ich pracownikom. Po trwających dwa dni targach dokumentacja fotograficzna została przeze mnie uporządkowana, zaś na podstawie sporządzonych notatek i wywiadów rozpoczęłam analizę.

W roku 2012 również wzięłam udział w podobnych targach, jednak wtedy nie przyjmowałam roli badaczki, a jedynie aktywnego uczestnika. Doświadczenie pozwoliło mi nie tylko na ocenę zmian czy trendów, lecz także na zwrócenie uwagi na wykluczenie pewnych aspektów marketingowych, które, jak się okazało, dla mojej analizy nie miały większego znaczenia. Moim głównym celem było odpowiedzenie na pytanie, jak kreowana jest podaż przestrzeni biurowej, jakie są oczekiwania oraz rzeczywiste realizacje.

\section{TARGI OFFICE DAYS 2013}

Każdego roku w Warszawie odbywają się targi Office Days, które mają na celu zaprezentowanie najnowszych trendów w wyposażeniu i usługach dla biur. Produkty i usługi prezentowane podczas targów są kierowane głównie do najemców zlokalizowanych 
w biurowcach klasy A, B+, B, czyli budynkach odpowiadających danemu standardowi, wybudowanych w ciągu ostatnich piętnastu lat. Najemcy wynajmujący takie powierzchnie biurowe to najczęściej przedstawiciele mniejszych i większych korporacji. Wystawcy starają się przewidzieć zapotrzebowanie na usługi i towary niezbędne przy funkcjonowaniu takiego biura. Jak informuje nas w przewodniku targów Katarzyna Cyprynowska, prezes firmy Nowy Adres S.A.: Sprawnie dziatajace biuro to nie tylko pokoje, biurka i dtugopisy - to także przyjazny użytkownikom projekt [...], sprawny przeptyw informacji, umiejętne gospodarowanie zasobami ${ }^{7}$.

\section{„WYGLĄD MIEJSCA PRACY ŚWIADCZY O KULTURZE PRACOWNIKA"}

W 2013 r. na targach Office Days na stanowiskach wystawowych promowały się aż sześćdziesiąt dwie firmy dostarczające wyposażenie i usługi dla biur. Według ogólnie dostępnego informatora, wystawcy zostali podzieleni na cztery grupy tematyczne:

1) Biurowce od A do Z (dziewiętnastu wystawców), znalazły się tu m.in.: druk, wykładziny, architektura wnętrz, meble przemysłowe/data center, systemy przechowywania, meble, stowarzyszenia zawodowe pracowników korporacji, fundacja o profilu ekologicznym zajmująca się promocją recyclingu w biurach.

2) Przyjazne biuro (dziewiętnastu wystawców), znalazły się tu m.in.: ścianki działowe, pokrycia podłogowe, podłogi podniesione, drukarki, energetyka, aranżacja i dekoracja wnętrz, palarnie, systemy bezpieczeństwa, usługi vendingowe (tj. automaty z kawą, herbatą oraz innymi napojami).

3) Technologiczne nowinki (dziewięciu wystawców), znalazły się tu m.in.: poligrafia, telekomunikacja, systemy bezpieczeństwa, tusze i tonery, wideokonferencje.

4) Świat usług (szesnastu wystawców), znalazły się tu m.in.: telekomunikacja, ochrona obiektów, szkolenia, budownictwo, maszyny do kawy, produkty spożywcze, magazynowanie, usługi szkoleniowe i doradcze.

Podział wystawców według proponowanych grup tematycznych nie wniósł żadnego uporządkowania, ponieważ wiele stanowisk o podobnej tematyce i rodzaju usługi powtarzało się nawet w trzech grupach tematycznych. Podobnie jak sami wystawcy, odebrałam proponowane kategorie jako przypadkowe.

Po analizie prezentowanych stanowisk (dokumentacja fotograficzna, przeprowadzone wywiady swobodne, analiza materiałów komercyjnych) oraz produktów i haseł reklamowych doszłam do wniosku, że zgodnie z prezentowaną przez wystawców wizją biura korporacji współczesny pracownik potrzebuje nowoczesnej przestrzeni biurowej, która przede wszystkim będzie zapewniała mu poczucie bezpieczeństwa i satysfakcji pracy w takim, a nie innym miejscu, wszystko to zaś ma prowadzić do wzmożonej kreatywności, efektywności, w atmosferze będącej połączeniem domowego zacisza i biznesowego szyku. Środowisko, w jakim przebywa jednostka, ma odzwierciedlać cechy - z perspektywy pracodawców - idealnego pracownika. Ponadto wygląd miejsca pracy

Biuletyn informacyjny „Office Days” wydany w formie ulotki. 
powinien wywoływać wśród pracowników podziw, dumę, a nawet poczucie ekskluzywności, co z kolei ma zachęcać ich do spędzania wielu godzin w tej nowoczesnej, prestiżowej, kreatywnej przestrzeni.

Handlowcy stoisk, które skupiały najwięcej zainteresowanych, podkreślali, iż dzięki ich usługom i produktom przestrzeń pracy będzie definiowana jako przyjazna dla jednostki, zaś pracodawca zdobędzie lub utrzyma opinię nowoczesnego i podążającego za najnowszymi trendami. Według wystawców przedmioty nie tylko mogą, ale wręcz powinny określać miejsce pracy. Niezależnie od branży pracodawca powinien zapewnić pracownikowi biuro, które będzie lepiej odzwierciedlać jego potrzeby niż domowe gniazdo. Zatem jakie elementy są ważne przy tworzeniu nowoczesnej przestrzeni pracy?

Architekci i dostawcy często zwracali uwagę na równowagę między praktycznością a estetyką. Ściany działowe mają na celu nie tylko wydzielenie powierzchni, lecz także jej odpowiednie wygłuszenie, co zapewni odpowiedni komfort pracy. Dodatkowo bacznie zwracano uwagę na walor estetyczny, korespondujący z takimi słowami, jak nowoczesny, stylowy, prestiżowy. Meble nie są już jedynie miejscem pracy, składającym się z biurka, kontenera i krzesła, dzisiejsze zaopatrzenie jest ergonomiczne, modne, często wykonane na zamówienie, dostosowane do indywidualnych potrzeb klienta. Podłoga nie jest już pokryta zwykłą wykładziną czy dywanem, a „pokryciem podłogowym” lub „wykładziną modułową", dostępną w wielu konfiguracjach kolorystycznych. Wnętrza mają być zaaranżowane gustownie, według światowych trendów, dlatego nie powinno w nich zabraknąć aranżacji naturalną zielenią czy kompozycji florystycznych. Zgodnie z przedstawionym obrazem współczesny pracownik wyraźnie odczuwa potrzebę poruszania się w pięknych wnętrzach, zaaranżowanych przez architektów i dekoratorów. W celu poprawnego wykonywania swojej pracy pracownik korporacji powinien korzystać z najnowszych rozwiązań teleinformatycznych. Absolutnie niezbędne stały się laptop, komórka, system wideokonferencji. Nie jest przypadkiem, iż wiele przymiotników określających prezentowane przedmioty i usługi zawiera przedrostek naj-: najlepszy, najnowszy, najszybszy. Pracownik korporacji powinien mieć poczucie, że pracuje w przestrzeni, która możliwie najlepiej zaspokaja jego nawet niezdefiniowane potrzeby.

Warto zwrócić uwagę na fakt, że wystawcy targów przedstawiają biuro nie tylko w kontekście pracy, lecz także jako sferę relaksu i przyjemności, miejsca, gdzie można napić się kawy, wypoczywać na leczniczym fotelu, prowadzić pogawędkę na wygodnych sofach, rozmawiając naprzemiennie o realizowanych projektach i sukcesach swoich pociech. Spędzać tym samym długie godziny w przestrzeni biurowej, nie czując potrzeby wykonywania żadnych czynności poza miejscem pracy. Stanowiska, które nawiązywały do rozrywek i relaksu w obrębie przestrzeni pracy, cieszyły się największą popularnością podczas targów wśród potencjalnych kontrahentów.

Jak pokazują statystyki, w pracy spędzamy ponad jedną trzecią dnia, od siedmiu do nawet dziesięciu godzin dziennie. Korzystając z bazy danych prowadzonej przez Eurostat, możemy odczytać, że w takich branżach, jak informacja i komunikacja, działalność finansowa i ubezpieczeniowa, działalność związana z obsługą rynku nieruchomości, działalność w zakresie usług administrowania i działalność wspierająca (które to najczęściej wynajmują komercyjnie powierzchnie biurowe w Warszawie), w roku 2012 
Polacy spędzali od 38,7 do 40,6 godz. tygodniowo w pracy, był to jeden z najwyższych wyników w Unii Europejskiej, w której w wymienionych branżach czas pracy wahał się od 34,2 do 38,9 godz. tygodniowo ${ }^{8}$. Więcej od Polaków pracują np. Czesi - nawet 40,9 godz. tygodniowo, i Słowacy - do 42,5 godz. tygodniowo. Spędzając wiele godzin w pracy, pracownicy oczekują zapewnienia przez pracodawcę nie tylko miejsca wykonywania obowiązków, lecz także innych usług dodatkowych, które pozwolą na społeczne przetrwanie. Przestrzeń pracy staje się poważną częścią przestrzeni życia, a coraz częściej obserwujemy, że dla niektórych wręcz jego głównym elementem.

\section{STANOWISKA WYSTAWIENNICZE - KONSTRUKCJA PERCEPCJI}

Wyposażenie każdego biura zaczyna się od jego podstawowej konstrukcji, w której skład wchodzą m.in. szklane ściany działowe, okablowanie komputerowe, klimatyzatory czy podwieszane sufity. Są to elementy, które można porównać do kategorii egzystencjalnych, bez których biuro nie spełnia swoich funkcji, a pracownik fizycznie nie może wykonywać swoich obowiązków. Przykładając hierarchię potrzeb Maslowa9 , moglibyśmy założyć, że jest to wypełnienie potrzeb podstawowych, tj. fizjologicznych i bezpieczeństwa. Niemożność zaspokojenia potrzeb podstawowych, w tym przypadku konstrukcyjnych, uniemożliwiałaby zaspokojenie kolejnych, wyższych. Finalnie pracodawca zakłada, że przestrzeń powinna zaspokoić potrzebę samorealizacji pracowników, ma to być miejsce, gdzie teoretycznie mogliby realizować swój potencjał. Aby osiągnąć etap samorealizacji, wkraczamy na głębszy poziom: elementów wyrażających przestrzeń, unikalnie aranżujących i dekorujących biuro. Ostatecznym elementem stają się dodatki, które indywidualnie określają miejsce pracy firmy czy branży. Warto zwrócić uwagę, że często dodatki, które poprzez swoją symbolikę znaku stają się również elementami wyrażającymi, nie reprezentują jedynie dóbr fizycznych, ale reprezentują cały wachlarz usług mających na celu zapewnić komfort, wytworzyć więzi czy zaufanie, spełnić potrzeby szacunku i zaufania ${ }^{10}$. Różnorodność pozwala na wybór określonej przestrzeni i zaspokojenie w niej większej liczby potrzeb. Pracodawca oferuje nowoczesne rozwiązania, zaś pracownik czerpie z nich to, co odpowiada jego aktualnemu zapotrzebowaniu. Kategoria dodatków pokazuje nam obraz firmy oraz jej wkład $\mathrm{w}$ indywidualne postrzeganie przestrzeni przez pracownika. Office manager wraz $\mathrm{z}$ architektem i nierzadko z przedstawicielem działu zarządzania zasobami ludzkimi kreuje przestrzeń, która z założenia powinna odzwierciedlać charakter i system pracy oraz oczekiwania pracowników. Taka kreacja pozwala na zachowanie komfortu i komunikacji pracowników, zaś w rezultacie teoretycznie powinna ponieść efektywność oraz zatrzymać najlepszych pracowników w zespołach.

Eurostat, Czas pracy w krajach Unii Europejskiej, dane za rok 2012, [online] http://epp.eurostat.ec.europa.eu/porta 1/page/portal/eurostat/home, 23 X 2013.

9 A. Maslow, Teoria hierarchii potrzeb, [w:] P. Zimbardo, Psychologia i życie, przeł. J. Radzicki, Warszawa 1994 , s. 676.

10 Tamże. 
Większoośc stanowisk posiadała jedną cechę wspólną, ich funkcja była silnie powiązana z podstawowymi czynnościami wykonywanymi w codziennym życiu związanym ze środowiskiem domowym. Od wielu lat obserwujemy silne przenikanie się kategorii życia codziennego w kontekście biurowym. Zaznaczenie i przenikanie się tych funkcji w obszarze pracy może świadczyć o potrzebie kreowania (a także łączenia) pewnych funkcjonalności i cech w sferze miejsca wykonywania obowiązków służbowych. Poprzez przenikanie się i łączenie powstają przestrzenie multifunkcjonalne, posiadające znacznie więcej cech i znaczeń niż suma ich elementów. Warto zwrócić uwagę, że podobną wielofunkcyjność urbaniści wyróżniali już w tzw. „przestrzeniach innowacyjnych", technopolis, których flagowym przykładem jest Dolina Krzemowa, zlokalizowana w północnej części amerykańskiego stanu Kalifornia. Przestrzenie takie były tworzone i rozwijane w procesie budowy tkanki miejskiej charakteryzującej się nowoczesnościa idbatością o jakość rozwiązań urbanistycznych oraz zgodnościa z zasadą zrównoważonego rozwoju. Tworzenie przestrzeni o wysokich walorach środowiskowych, powiazanej z ośrodkami przemystu high-tech oraz towarzyszacymi im terenami uniwersyteckimi, naukowo-badawczymi i ustugowymi, wynika ze świadomości nierozerwalnego związku między sukcesem gospodarczym a dziataniami urbanistycznymi ${ }^{11}$.

W dobie przedsiębiorczości i wysoko cenionej pracy pracownicy poświęcają swoim obowiązkom służbowym nawet kilkanaście godzin dziennie. Wymusza to na pracodawcach stworzenie przestrzeni, która będzie zaspokajać coraz to nowsze i złożone potrzeby pracowników. Przykład technopolii pokazuje, że wprowadzenie wysokiej jakości środowiska pracy, która została zastosowana na wielu polach przestrzeni życiowej, ma na celu kreację wyobrażenia firmy przyjaznej pracownikowi, która dba o swoją wysoko wykwalifikowaną kadrę. Podobnie opisywali technopolie początku lat 90. XX w. Manuel Castells i Peter Hall, w których to na spójnej urbanistycznie przestrzeni były ulokowane biura, rekreacyjne tereny zielone i kampusy uniwersyteckie, o charakterze półpublicznym, społecznym $^{12}$. Multifunkcjonalność przestrzeni zaprocentowała efektem synergii, co spowodowało zmiany percepcji miejsca pracy wśród pracowników. Ponadto sama przestrzeń biurowa nabierała charakteru różnych ról społecznych odgrywanych przez człowieka ${ }^{13}$.

Interesujące wydaje się pytanie, po której stronie, pracodawców czy pracowników, pojawił się po raz pierwszy bodziec do realizacji wielofunkcyjnej przestrzeni? Gdzie możemy znaleźć źródło obserwowanego trendu? Dlaczego powierzchnie te dążą do niemożliwej perfekcji we wszystkich budowanych mikrośrodowiskach, imitując świat realny? Desygnaty przedmiotów kreujące przestrzeń, które zostały wytworzone przez dostawców, takich jak architekci, designerzy, a w końcu office managerowie i dyrektorzy personalni, nadają określony charakter korpopracy, dążąc niemalże do obrazu pełni wszelkiego bytu absolutnie doskonałego, gdzie jednostka osiąga zarówno spokój, jak i samorealizację.

11 M. Wdowiarz-Bilska, Miejsce pracy, zamieszkania i wypoczynku w przestrzeniach innowacyjnych, „Czasopismo Techniczne. Architektura” 2010, Vol. 107, z. 3-A, [online] http://suw.biblos.pk.edu.pl/ resources/i2/i5/i2/i5/r2525/WdowiarzBilskaM_MiejscePracy.pdf, 23 X 2013.

12 M. Castells, P. Hall, Technopoles of the World, London-New York 1994.

13 M. R. Hall, E. Hall, Czwarty wymiar w architekturze. Studium o wptywie budynku na zachowanie cztowieka, przeł. R. Nowakowski, Warszawa 2001, Spectrum. 
Jak zostałam poinformowana przez kilku handlowców, analizując prestiż przestrzeni pracy, oprócz fizycznego miejsca pracy oraz rodzaju wykonywanych usług powinniśmy mieć na względzie także wygląd i zachowanie zatrudnionych pracowników. Szeroko dostępne są usługi „podniesienia prestiżu” pracowników, za pomocą stylizacji ubioru zgodnej ze standardami korporacyjnymi, a także kursów biznesowych zachowań. Wystawcami na targach Office Days byli Szkoła Stylu oraz „uniformy biurowe”. Jednostka, która przebywa w prestiżowym biurze, także powinna odpowiednio się prezentować, a raczej dopasować do otoczenia. Szkoła Stylu proponowała usługi w zakresie stylizacji odpowiadających stylowi korporacyjnemu oraz warsztatów dotyczących etykiety biznesowej i savoir-vivre'u. W kazdej firmie obowiazują pewne zasady ubioru. Nawet jeśli nie ma ustalonych sztywnych regut dress code, to pewnych granic dobrego smaku nie należy przekraczać. Niestety, pracownicy nie zawsze zdają sobie z tego sprawę. Odstonięte stopy sa dobre na plażę i wakacyjne wyjazdy, zbyt mocno wycięty dekolt może zniechęcić do wspótpracy, a zbyt duża marynarka świadczyć będzie o nieumiejętności dopasowania stroju do sylwetki. Wprowadzamy zasady, których stosowanie zapewni komfort wspótpracownikom, ale także klientom biznesowym, $z$ którymi spotykamy się w różnych okolicznościach i miejscach. O tym, jak zostaniemy odebrani, decyduje w pierwszej kolejności nasz wyglad ${ }^{14}$. $Z$ tego wpisu umieszczonego na stronie internetowej Szkoły Stylu możemy wnioskować, że idealne biuro powinno posiadać także idealnych pracowników, którzy będą odpowiednim elementem dopełniającym zaplanowaną przestrzeń.

Inicjatywa i kreatywność pracownika to często cechy wielce pożądane przez pracodawcę. Jak jednak realizować swój potencjał, kiedy nawet w sferze tak osobistej jak wygląd zewnętrzny są z góry ustalone reguły, którym wypadałoby się podporządkować? Każdy pracownik korporacji stanie przed moralnym wyborem. Jednak analiza własnych potrzeb i moralności, wartość zachowania „ja”, może przegrać ze środowiskiem, którego desygnaty to synonimy sukcesu. Wybór wydaje się racjonalny, gdyż w przypadku niedostosowania się sukcesu nie osiągniemy, nie zapewnimy „komfortu współpracownikom oraz klientom biznesowym", a tym samym nie zostaniemy zaakceptowani przez środowisko, do którego potencjalnie aspirujemy.

\section{DOMOWE BIURO}

Stanowiska, które prezentowały ekspresy do kawy oraz zaparzacze do herbaty, zgromadziły największą liczbę odwiedzających gości. Sprzedawcy zachwalali nie tylko nowe rozwiązania czy lepszą kawę, lecz także podkreślali wagę urządzenia, jakim jest kawiarka, a właściwie przestrzeń, jaką tworzy podobne urządzenie w każdym przedsiębiorstwie. Automat znajduje się w niemalże każdej firmie, zaś powierzchnia wokół niego jest identyfikowana $\mathrm{z}$ chwilą przerwy, relaksu, a także życia społecznego w pracy. Urządzenia te są przystosowane do pracy w różnych miejscach - kuchniach, strefach relaksu, przestrzeniach otwartych typu open space. Zaopatrzenie pracowników w świe-

14 Oferta dla firm, Szkoła Stylu, [online] http://www.szkolastylu.pl/pl/index.php/dla-firm, 23 X 2013. 
żą kawę staje się jednym z najważniejszych celów, biorąc pod uwagę czas wolny spędzany przez pracowników korporacji w biurze. Jak słusznie zauważyli zarówno sprzedawcy, jak i office managerowie, przestrzeń wokół automatu z kawą jest przestrzenią społeczną, która funkcjonuje na granicy dwóch światów: biurowego i prywatnego. Podczas przerwy pracownicy nie tylko odpoczywają od obowiązków służbowych, lecz także socjalizują się z kolegami w wymiarze służbowym i prywatnym. Rozmowy przeprowadzane w wolnym czasie, spędzonym np. na przerwie kawowej, należą często do kuluarów, które są integralną częścią życia biurowego.

Wystawcy proponują dla biur rozwiązania urządzeń kuchennych znajdujących się w każdym domu. Możemy wnioskować, że przestrzeń biurowa powinna zaspokajać wszelkie potrzeby pracownika, a kuchenki mikrofalowe, czajniki, podgrzewacze, dyspozytory wody, wyciskarki do soków mają uatrakcyjnić wielogodzinny czas spędzony poza domem. Oglądając kolejne stanowiska z drobnym AGD, jako codzienny użytkownik wymienionych sprzętów nie odniosłam wrażenia, że poruszam wśród przedmiotów oferowanych do biur, a jedynie wśród produktów należących do kategorii artykułów gospodarstwa domowego. Moją uwagę zwrócił fakt, że przykładowe AGD pokazywane na wystawie odzwierciedlały to, co znajduje się w domowej kuchni każdego z pracowników. Pracodawcy próbują zaaranżować środowisko pracy tak, by jak najbardziej przypominało dom, czy nawet zatrzeć tę granicę.

„Domową atmosferę" podkreślały także stanowiska prezentujące aranżację wnętrz naturalną roślinnością. Kwiaty mogą zostać kupione lub wypożyczone. Kompozycje są nieograniczone, a jedyną barierą dla potencjalnego nabywcy może być cena. Jak zapewniają architekci, dbałość o szczegół pozwoli na pracę w warunkach „naturalnie pięknych". Oczywiście, podobnie jak w przypadku innych produktów, wystawcy podkreślali najwyższą jakość oferowanych usług, przystosowanych do nowoczesnych korporacyjnych przestrzeni biurowych. Moją uwagę zwróciła asocjacja dwóch często używanych znaczeń przymiotników. Jak już zostało wspomniane, z jednej strony skupiamy uwagę na odzwierciedleniu domowego zacisza, ze wszystkimi jego cechami, które kojarzą nam się z bezpieczeństwem, spokojem, przyjemnością lub wygodą, z drugiej zaś strony oferowane dodatki w kontekście biurowym są określane przymiotnikami naj-, oddającymi poczucie luksusu i wyjątkowości. Najlepszej jakości kawa, najpiękniejsze aranżacje kwiatowe, najtrwalsza wykładzina, najsmaczniejsze owoce. Ten dualizm był obecny na wielu stanowiskach. To, co zwróciło moją uwagę, to naprzemienne przenikanie się oraz walka między kategorią domowe i biurowe, jak gdyby nie było jednoznacznie określone, która z kategorii powinna dominować, która jest ważniejsza z punktu widzenia pracodawcy, pracownika. Każda kategoria ma swoje dystynkcje w społeczeństwie, w postawach i dążeniach ludzi. Analizując postawy dostawców oraz sposób przedstawienia dóbr i usług biurowych, odniosłam wrażenie, że próbują oni stworzyć kategorię superproduktu domowo-biurowego, który posiadałby cechy obu przestrzeni, przez większość społeczeństwa odbieranych pozytywnie. Znaczna część jednostek dąży do zaspokojenia potrzeby stworzenia domowego ogniska oraz nieustannej potrzeby gromadzenia wartości materialnych, które dodatkowo posiadają status określany jako luksusowy. Przykładowo, mogłaby być to przestrzeń o cechach, które wywołują poczucie 
bezpieczeństwa i wygody, ale jednocześnie są w swojej kategorii najbardziej nowoczesne, najsmaczniejsze, najlepsze.

Kategorię usług kojarzonych z domem doskonale uzupełniały stanowiska skupiające swoją uwagę na zdrowiu. Przez wystawców oferowane były m.in. fotele biurowe, które dzięki unikalnym rozwiązaniom nie powodują bólów pleców podczas wielogodzinnego siedzenia za biurkiem. Podobnie jak u innych dostawców, mamy tu możliwość obcowania z superproduktem, który dodatkowo odnosi się do zdrowia, stanowiącego w społeczeństwie jedną z fundamentalnych wartości. Hasłem reklamowym usługodawcy był zwrot: „Biuro bez bólu pleców”. Warto zwrócić uwagę, że według hasła reklamowego biuro jako przestrzeń, niebędąca organizmem żywym, może odczuwać ból pleców. O ile w przypadku jednostki nie jest to kwestia dyskusyjna, o tyle w przypadku trudnej do określenia materii, jaką jest przestrzeń biurowa, jakiekolwiek odczuwanie bodźców stoi pod dużym znakiem zapytania. $Z$ tego nadania przestrzeni biurowej formy materialnej czy wręcz ożywionej wnioskuję, że wystawcy poniekąd definiują biuro jako zespół jednostek, pracowników, którzy wypełniają swoich istnieniem społecznym przestrzeń. Tym samym na wzór społeczeństwa, które może być rozumiane jako rozwijający się żywy organizm, biuro nabiera cech materii ożywionej, wchodząc w interakcje z podmiotami, istotami żywymi czy odczuwając bodźce.

Moją uwagę zwróciły szczególnie wystawy kabin do palenia papierosów i pochłaniacze dymu. Pomimo że pracodawcy nie mają obowiązku zapewnienia przestrzeni mającej służyć tym celom, coraz więcej firm stara się sprostać oczekiwaniom pracowników i umożliwić im palenie poprzez stworzenie miejsca, w którym czuliby się komfortowo. Zgodnie ze wspomnianymi już kategoriami przedstawionymi przez Abrahama Maslowa kabina służy najprawdopodobniej zaspokojeniu potrzeby przyjemności. Analiza źródeł internetowych wykazuje, że kategoria zaspokojenia przyjemności jest bardzo szerokim pojęciem i będzie wymagać osobnych podkategorii. Według artykułów pojawiających się $\mathrm{w}$ prasie ${ }^{15}$ pracodawcy coraz częściej nagradzają swoich pracowników pozafinansowo, oferując im formy rozrywki w przestrzeni biurowej, np. kącik z konsolą komputerową, automatem do gier, piłkarzykami czy stołem do ping-ponga. Kilka lat temu rewolucji w zakresie aranżacji przestrzeni pracy pracowników dokonał Google, publikując zdjęcia z powierzchni biurowej zrealizowanej w Zurychu, jednak dziś obraz konsultanta siedzącegow biurze, w koszulce i krótkich spodenkach, gdzie w części „rozrywkowej” koledzy z biura grają w piłkarzyki, a w kuchni jest zawsze pełna zdrowej żywności lodówka, nie jest już wielkim zaskoczeniem, znanym jedynie z amerykańskich korporacji1'.

Czy takie są oczekiwania młodych pracowników korporacji? Co jest dla ich ważniejsze: przestrzeń relaksu i rozrywki czy też biuro odpowiadające innym kategoriom,

15 Rozrywka w firmie. Relaks czy demotywacja?, Wp.pl, 4 V 2011, [online] http://praca.wp.pl/title, Rozrywka-w-firmie-Relaks-czy-demotywacja,wid,13373514,wiadomosc.html?ticaid=11106a, $23 \mathrm{X}$ 2013; Kreatywna przestrzeń nie tylko w Google, Reklama w Internecie, 15 VII 2013, [online] http:// www.reklamawinternecie.pl/1636-kreatywna-przestrzen-nie-tylko-w-google.html, 23 X 2013.

16 „Siedzę $w$ biurze $w$ krótkich spodenkach, a obok koledzy graja w pitkarzyki”. List 30-latka, „Gazeta Wyborcza” 2013, 17 V, [online] http://m.wiadomosci.gazeta.pl/wiadomosci/1,117915,13928448, Siedze_w_biurze_w_krotkich_spodenkach_a_obok_koledzy.html, 23 X 2013. 
takim jak prestiż, zacisze domowego ogniska? Podczas tegorocznych targów Office Days na żadnym stanowisku nie znalazłam takich produktów, jak stoły czy konsole do gry, jednak nie chciałabym wyciągać daleko idących wniosków, że gadżety tego typu nie powinny znaleźć się w sferze kreowanej rzeczywistości biurowej lub, co więcej, że ich obecność nie jest oczekiwana przez młodych pracowników.

Jakim obrazem nowoczesnej przestrzeni pracy posługują się dostawcy wyposażenia i usług dla biur?

Posługując się definicją przestrzeni społecznej Bohdana Jałowieckiego i Marka S. Szczepańskiego, która charakteryzuje specyficzne rodzaje ludzkiej działalności (np. przestrzeni produkcji), można stwierdzić, że kreacja przestrzeni pracy korporacji dokonana przez grupę dostawców wyposażenia i usług dla biur przedstawia pewien wymiar rzeczywistości spotecznej ${ }^{17}$. Oprócz z góry określonych oraz unikalnych funkcji i formy materialnej wyróżnia się także pewnymi społecznie uwarunkowanymi cechami. Wizja przedstawionej przestrzeni jest przeznaczona dla wąskiej grupy pracowników korporacji. Prezentowane koncepcje biura poprzez swoje uwarunkowania fizyczno-geometryczne, zdaniem strony reprezentującej podaż, dążą do oddania stylu życia grupy społecznej lub, co więcej, wyznaczają trendy, za którymi grupa powinna podążać. W tym ujęciu przestrzeń pracy jest równoznaczna z terytorium użytkowanym przez grupę społeczną o określonych cechach ${ }^{18}$. Analizując percepcję oraz deklaracje grupy strony podażowej, wnioskuję, że celem dostawców jest zaspokojenie potrzeb grupy pracowników korporacji. Zróżnicowanie materii i usług, a zarazem popyt, badany podczas targów na poziomie deklaratywnym, mogłyby wskazywać, że przedstawiane koncepcje są przemyślane i odpowiadają na zmieniające się oczekiwania pracowników i warunki ich funkcjonowania w przestrzeni. Co więcej, kreują „wartości przestrzenne” mające znamiona sukcesu, indywidualności i kreatywności. Jednak nikt z reprezentantów dostawców nie potrafił przywołać badań dotyczących potencjalnych potrzeb pracowników korporacji. Niewątpliwie ważna wydaje się analiza dwóch stanowisk reprezentujących stronę popytową i podażową przestrzeni pracy. Na dalszym etapie moich badań planuję przebadać grupę popytową, pracowników korporacji, ich koncepcję przestrzeni, potrzeby odnośnie do powierzchni pracy oraz wizję biura. Konfrontacja wizji pracowników oraz dostawców pozwoli mi nie tylko na opis każdej z przestrzeni, lecz także na wskazanie bodźców, które wpływają na jej kształt i powodują jej zmiany w ostatnich kilku dekadach.

\section{HIPERPRAWDZIWA PRZESTRZEŃ KORPORACJI}

Poddając badaną przestrzeń dalszej analizie, odniosłam wrażenie, że poruszam się po idealnej przestrzeni, hiperprzestrzeni, gdzie hiperprawdziwe staje się ważniejsze niż prawdziwe czy rzeczywiste, jako efekt zastąienia rzeczywistości znakami rzeczywisto-

17 B. Jałowiecki, M. S. Szczepański, Miasto i przestrzeń w perspektywie socjologicznej, Warszawa 2006, s. 316, Wyktady z Socjologii, t. 4.

18 Tamże, s. 315-405. 
$s_{c} i^{19}$. Przedmioty i dodatki tworzą idealną przestrzeń korporacji, ta zaś podporządkowuje sobie wizerunek ludzi, ich wygląd i zachowanie. Każdy element tego obrazu ma silne cechy definiujące, spójne, z góry określone funkcje graniczące między tym, co biurowe, a tym, co domowe, dające nam relaks. Czy ta przestrzeń jest jeszcze prawdziwa? Odnoszę wrażenie, że w gąszczu znaków, które w tej przestrzeni są oderwane od podstawowych funkcji, jakie powinien spełniać przedmiot, tracimy sens wykonywania danych aktywności. Poruszamy się wświecie przedmiotów - fetyszy i powszechnej estetyzacji20

W książce Symulakry i symulacja Jean Baudrillard ogłasza apokaliptyczną wizję końca sensu, znaczenia i referencji, która dokładnie odzwierciedla sens spreparowanej hiperrzeczywistości. Jako przykład Baudrillard przedstawia postać symulanta, który faktycznie nie jest chory, ale wywołuje w sobie symptomy choroby, które są rzeczywiste. W tej koncepcji hiperrzeczywistość będzie się składała głównie z objawów. Choroba nie jest prawdziwa, ale przecież choroba z gruntu rzeczy nas nie interesuje. Proponowana przez korporacje przestrzeń biurowa jest symulantem, gdzie mikroprzestrzeń środowiska pracy, będąca jedynie wycinkiem życia pracowników, próbuje stać się miejscem samorealizacji innych najważniejszych obszarów ich aktywności, takich jak dom czy rodzina, naśladując czy też symulując ich funkcje. Relacje społeczne są zastąpione przez przedmioty, które nadają działaniom określone znaczenia, a samym pracownikom upragniony status. Dążymy do doskonałości, jak pisał Baudrillard: bezużytecznej doskonałości.

System, który tworzy hiperrzeczywistość przestrzeni biurowej, jest bardzo uporządkowany. Można rzecz - przesadnie uporządkowany. Pomimo deklaracji dostawców o elastyczności powierzchni „uszytej na miarę” dla konkretnych grup pracowników, zakres możliwości ruchów jest bardzo ograniczony. Pracownik korporacji jest świadomy tego, że nie może spodziewać się prywatnego gabinetu, biurko, ze względu na techniczną aranżację, znajduje się w wyznaczonym miejscu, zasady korzystania z kuchni są przekazywane przez innych, bardziej doświadczonych współpracowników, a strefy relaksu nakazują relaksować się w określony sposób. Funkcje są z góry ustalone, aby hiperrzeczywistość mogła przetrwać jako spektakl o przewidywalnym zakończeniu, którego scenariusz napisał pracodawca. Baudrillard podobnie charakteryzuje hipermarket jest to model wszelkiej przysztejpostaci kontrolowanej socjalizacji, ponowne scatościowanie i ujednolicenie w formie jednorodnej czasoprzestrzeni wszelkich rozproszonych funkcji ciata $i$ zycia spotecznego, czasoprzestrzeń wszelkiej operacyjnej symulacji życia spotecznego ${ }^{21}$.

Baudrillard zauważa, że obraz, który staje się hiperrzeczywisty, przechodzi przez kolejne stadia: na początku rozumiany jest jako odzwierciedlenie głębokiej rzeczywistości („właściwy pozór”), następnie tę rzeczywistość skrywa i wypacza („niewłaściwy pozór”), w kolejnym stadium skrywa nieobecność głębokiej rzeczywistości („udaje, że jest pozorem”), by ostatecznie stracić związek z jakąkolwiek rzeczywistością („staje się symulakrem samego siebie"). Rozważam przyjęcie tej teorii w przypadku percep-

19 J. Baudrillard, Symulakry i symulacja, przeł. S. Królak, Warszawa 2005, s. 7.

20 K. Machtyl, Digitalizacja kultury. Jeana Baudrillarda diagnoza wspótczesności, „Kultura i Historia” 2012, Vol. 21, [online] http://www.kulturaihistoria.umcs.lublin.pl/archives/3336, 3 III 2012.

21 J. Baudrillard, Symulakry..., s. 97. 
cji przestrzeni pracy młodych pracowników biurowych, którzy wkraczają w świat korporacji. Początkowo niedoświadczony pracownik może odebrać przestrzeń oferowaną przez korporację jako spójną, lepszą rzeczywistość, uporządkowaną, wielowymiarową, dającą szansę na karierę i rozwój. Następnie pracownik dowiaduje się o standardach funkcjonowania w tej przestrzeni, poznaje jej reguły, indywidualne zasady poruszania się i współpracy, w końcu przestrzeń biurowa odcina się od „zwykłej rzeczywistości”, staje się niemożliwa do znalezienia w środowisku, w którym do tej pory przebywał pracownik. Wszystkie cechy dotychczasowych miejsc są spotęgowane w jednej, niewielkiej przestrzeni biurowej. Przedmioty umieszczone w biurze odnoszą się do rzeczywistości, ale posiadają już swoje dodatkowe cechy i funkcje. Stają się przedmiotami niezastępowalnymi, idealnymi, do których z definicji każdy powinien dążyć. Poruszamy się w przestrzeni, która powinna zapewnić nam wypracowanie sukcesu - jedynej słusznej drogi w celu osiągnięcia samorealizacji.

Po głębszej analizie stwierdzamy, że oferowana przestrzeń nie potrafi wykreować prawdziwego odzwierciedlenia tych wszystkich środowisk. Symulakry w zestawieniu z realnym domem i realnymi przyjaciółmi stają się jedynie pustymi przedmiotami. Automat do kawy nie zawsze będzie miejscem spotkań, rozmów, plotek, nie zawsze pracownik poczuje luksus świeżo zmielonych kubańskich czy brazylijskich ziaren, nie zawsze będzie chciał rozumieć tę chwilę jako moment relaksu podobny do tego, jaki odczuwa w domu. Po kilkunastu godzinach pracy przerwa na kawę może stać się koniecznością, a nie przyjemnością. Pojawia się pytanie, czy nowoczesna przestrzeń pracy uwodzi jedynie znakami pozbawionymi znaczenia. Co się stanie, jeśli dotychczasowe znaczenia przestaną być atrakcyjne dla nowych pracowników?

Dzisiaj pracodawcy podkreślają nowoczesne rozwiązania- doskonałe złudzenia życia społecznego - mając na celu zaznaczenie niezwykłości oferowanej hiperprzestrzeni. Jest ona odzwierciedleniem biura, domu, wypoczynku, posiada znamiona tych środowisk, doskonale imituje ich wymiar symboliczny, transparentnie kreuje idealne wyobrażenie o nich i ostatecznie odcina się od ich słabości, oferując przestrzeń pozbawioną chaosu i przypadkowości. Pracownik przekonuje się, że oferowane biuro spełnia ramowe wymagania nie tylko środowiska pracy, oferując przy tym wizualnie pożądaną formę, uporządkowanie oraz poczucie doskonałości, której trudno spodziewać się w realnym świecie.

\section{BIBLIOGRAFIA}

Baudrillard J., O uwodzeniu, przeł. J. Margański, Warszawa 2005.

Baudrillard J., Symulakry i symulacja, przeł. S. Królak, Warszawa 2005.

Buczyńska-Garewicz H., Miejsca, strony, okolice. Przyczynek do fenomenologii przestrzeni, Kraków 2006, Horyzonty Nowoczesności, 49.

Castells M., Hall P., Technopoles of the World, London-New York 1994.

Domka-Rybka A., Sunrise System Bydgoszcz. Doradzaja w marketingu internetowym i graja w pitkarzyki, Strefa Biznesu pomorska.pl, 7 I 2013, [online] http://www.strefabiznesu. 
pomorska.pl/artykul/sunrise-system-bydgoszcz-doradzaja-w-marketingu-internetowym-i-graja-w-pilkarzyki-zdjecia.

Eurostat, Czas pracy w krajach Unii Europejskiej, dane za rok 2012, [online] http://epp.eurostat. ec.europa.eu/portal/page/portal/eurostat/home, 23 X 2013.

Hall E., Poza kulturą, przeł. E. Goździak, Warszawa 1984.

Hall M. R., Hall E., Czwarty wymiar w architekturze. Studium o wptywie budynku na zachowanie cztowieka, przeł. R. Nowakowski, Warszawa 2001, Spectrum.

Jałowiecki B., Spoteczne wytwarzanie przestrzeni, Warszawa 1988.

Jałowiecki B., Szczepański M. S., Miasto i przestrzeń w perspektywie socjologicznej, Warszawa 2006, Wyktady z Socjologii, t. 4.

Kreatywna przestrzeń nie tylko w Google, Reklama w Internecie, 15 VII 2013, [online] http:// www.reklamawinternecie.pl/1636-kreatywna-przestrzen-nie-tylko-w-google.html.

Machtyl K.,Digitalizacjakultury. Jeana Baudrillardadiagnozawspótczesności,„Kulturai Historia” 2012, Vol. 21, [online] http://www.kulturaihistoria.umcs.lublin.pl/archives/3336.

Maslow A., Teoria hierarchii potrzeb, [w:] P. Zimbardo, Psychologia i życie, przeł. J. Radzicki, Warszawa 1994.

Mykicka E., Między teoria symulakrum a portretem. Portrety Anety Grzeszykowskiej $i$ Portrety Thomasa Ruffa, „Polisemia. Naukowe Czasopismo Internetowe” 2012, nr 1, [online] http:// www.polisemia.com.pl/numery-czasopisma/numer-12012-8/midzy-teori-symulakrum-a-portretem-portrety-anety-grzeszykowskiej-i-portrety-thomasa-ruffa.

Oferta dla firm, Szkoła Stylu, [online] http://www.szkolastylu.pl/pl/index.php/dla-firm.

Rozrywka w firmie. Relaks czy demotywacja?, Wp.pl, 4 V 2011, [online] http://praca. wp.pl/title,Rozrywka-w-firmie-Relaks-czy-demotywacja,wid,13373514,wiadomosc. html?ticaid=11106a.

„Siedzę w biurze w krótkich spodenkach, a obok koledzy grają w pitkarzyki”. List 30-latka, „Gazeta Wyborcza” 2013, 17 V, [online] http://m.wiadomosci.gazeta.pl/wiadomosci/1,117915, 13928448,_Siedze_w_biurze_w_krotkich_spodenkach_a_obok_koledzy.html.

Wdowiarz-Bilska M., Miejsce pracy, zamieszkania i wypoczynku w przestrzeniach innowacyjnych, „Czasopismo Techniczne. Architektura” 2010, Vol. 107, z. 3-A, [online] http://suw.biblos. pk.edu.pl/resources/i2/i5/i2/i5/r2525/WdowiarzBilskaM_MiejscePracy.pdf.

Ziółkowski J., Postowie, [w:] A. Wallis, Socjologia przestrzeni, wybór i oprac. E. Grabska-Wallis, M. Ofierska, Warszawa 1990.

Znaniecki F., Socjologiczne podstawy ekologii ludzkiej, „Ruch Prawniczy, Ekonomiczny i Socjologiczny" 1938, z. 1.

Znaniecki F., Zagadnienie wartości w filozofii, Warszawa 1910, Wydawnictwo „Przegladu Filozoficznego".

Mgr Katarzyna TASAREK-SKROK - doktorantka w Katedrze Socjologii i Antropologii Obyczajów i Prawa Instytutu Stosowanych Nauk Społecznych UW, absolwentka tego wydziału. Główne zainteresowania naukowe: przestrzeń społeczna, przestrzeń pracy, urbanistyka, a także zagadnienia dotyczące przemian wizualności. 